\title{
PENINGKATAN HASIL BELAJAR PEMBELAJARAN TEMATIK SUB TEMA KERAGAMAN SUKU BANGSA DAN AGAMA DI NEGERIKU MENGGUNAKAN MODEL TWO STAY TWO STRAY (TSTS) PESERTA DIDIK KELAS IV DI UPT.SD NEGERI 16 BARINGIN
}

\author{
WISWI AYU SYAFNI \\ wiswiayusyafni16@gmail.com
}

\begin{abstract}
This study aims to determine: a) Thematic learning outcomes in the SubTheme of Ethnic and Religious Diversity in my Country, students before using the Two Stay Two Stray learning model in Thematic learning of the Sub-Theme of Ethnic and Religious Diversity in My Country b) Application of the Two Stay model Two Strays on Thematic learning of the Sub-Theme of Ethnic and Religious Diversity in My Country, c) Improved learning outcomes in Thematic learning of the Sub-Theme of Ethnic and Religious Diversity in My Country after using the Two Stay Two Stray model of class IV UPT. SD Negeri 16 Baringin. The subjects in this classroom action research were UPT students. SD Negeri 16 Baringin class IV, totaling 35 students consisting of 19 boys and 16 girls, while the object in this study was the thematic learning outcomes of the sub-theme of ethnic and religious diversity in my country using the Two Stay Two Stray learning model. In the pre-test before using the Two Stay Two Stray model, the average score of students was 68.29, namely 19 people (54.29\%) who achieved learning completeness and 16 people (45.71\%) who had not reached learning completeness, in the first cycle the class average value obtained was 74.89 , the number of students who achieved learning completeness was 26 people (74.29\%) and students who had not reached learning completeness were 9 people $(25.71 \%)$. While the learning outcomes test cycle II the class average value obtained by students was 84.57 , students who achieved learning completeness were 31 people $(88.57 \%)$ and the number of students who did not complete learning was 4 people (11.43\%). So using the Two Stay Two Stray learning model can improve the learning outcomes of Thematic learning in the Sub-Theme of Ethnic and Religious Diversity in My Country. Keywords: Two Stay Two Stray Method. Learning Outcomes, Thematic.
\end{abstract}

Abstrak: Penelitian ini bertujuan untuk mengetahui: a) hasil belajar pembelajaran Tematik Sub Tema Keragaman Suku Bangsa dan Agama di Negeriku siswa sebelum menggunakan model pembelajaran Two Stay Two Stray pada pembelajaran Tematik Sub Tema Keragaman Suku Bangsa dan Agama di Negeriku b) Penerapan model Two Stay Two Stray pada pembelajaran Tematik Sub Tema Keragaman Suku Bangsa dan Agama di Negeriku, c) Peningkatan hasil belajar pada pembelajaran Tematik Sub Tema Keragaman Suku Bangsa dan Agama di Negeriku setelah menggunakan model Two Stay Two Stray kelas IV UPT. SD Negeri 16 Baringin. Subjek dalam penelitian tindakan kelas ini adalah siswa UPT. SD Negeri 16 Baringin kelas IV yang berjumlah 35 peserta didik terdiri dari 19 laki-laki dan 16 perempuan, sedangkan objek dalam penelitian ini adalah hasil belajar pembelajaran Tematik Sub Tema Keragaman Suku Bangsa dan Agama di Negeriku dengan menggunakan model pembelajaran Two Stay Two Stray. Pada tes awal (Pre-Test) sebelum menggunakan model Two Stay Two Stray nilai rata- rata peserta didik sebesar 68,29 yaitu 19 orang $(54,29 \%)$ yang mencapai ketuntasan belajar dan 16 orang $(45,71 \%)$ yang belum mencapai ketuntasan belajar, pada siklus I nilai rata- rata kelas yang di dapat sebesar 74,89 jumlah peserta didik 
yang mencapai ketuntasan belajar sebanyak 26 orang $(74,29 \%)$ dan siswa yang belum mencapai ketuntasan belajar sebanyak 9 orang $(25,71 \%)$. Sedangkan tes hasil belajar siklus II nilai rata- rata kelas yang didapat peserta didik sebesar 84,57 , peserta didik yang mencapai ketuntasan belajar sebanyak 31 orang $(88,57 \%)$ dan jumlah peserta didik yang tidak tuntas belajar sebanyak 4 orang $(11,43 \%)$. Maka menggunakan model pembelajaran Two Stay Two Stray dapat meningkatkan hasil belajar pembelajaran Tematik Sub Tema Keragaman Suku Bangsa dan Agama di Negeriku.

Kata Kunci : Metode Two Stay Two Stray. Hasil Belajar, Tematik.

\section{A. Pendahuluan}

Sebagai lembaga pendidikan dasar, Madrasah Ibtidaiyah/Sekolah Dasar memiliki tugas dan fungsi yang sangat strategis dalam rangka membangun fondasi pengetahuan dengan membekali teori dan praktik tentang disiplin ilmu tertentu kepada peserta didik. Untuk itu, lembaga pendidikan dasar dituntut untuk dapat menyelenggarakan proses pendidikan yang dapat mencapai tujuan pendidikan nasional yaitu, mengembangkan potensi peserta didik agar menjadi manusia yang beriman dan bertakwa kepada Tuhan Yang Maha Esa, berakhlak mulia, sehat, berilmu, cakap, kreatif, mandiri, dan menjadi warga negara yang demokratis dan bertanggung jawab.

Pendidikan mempunyai peranan yang sangat penting dalam menciptakan sumber daya manusia (SDM) yang berkualitas. Diungkapkan secara tegas oleh Komisi Pendidikan bahwa prinsip fundamental pendidikan hendaklah mampu memberikan kontribusi untuk perkembangan seutuhnya setiap orang, jiwa dan raga, intelegensi, kepekaan, rasa etika, tanggung jawab pribadi dan nilai-nilai spiritual. Berdasarkan prinsip tersebut diharapkan pembelajaran di sekolah dapat membekali anak sejak dini dengan kemampuan berpikir logis, analitis, sistematis, kritis, kreatif serta dalam hal kemampuan bekerja sama.

Pembelajaran merupakan proses alamiah setiap orang sebagai hasil dari memori, kognisi, dan metakognisi yang berpengaruh terhadap pemahaman. Hasil dari proses belajar-mengajar akan tampak pada setiap perubahan aspek pengetahuan, pengertian, kebiasaan, keterampilan, apresiasi, emosional, hubungan sosial, jasmani, etis atau budi pekerti, dan sikap. Pembelajaran tematik adalah program pembelajaran yang berangkat dari satu tema atau topik tertentu dan kemudian dielaborasikan dari berbagai aspek atau ditinjau dari berbagai perspektif mata pelajaran yang biasa diajarkan di sekolah. Pembelajaran tematik merupakan salah satu model pembelajaran terpadu (integrated instruction) yang merupakan suatu sistem pembelajaran yang memungkinkan siswa, baik secara individu maupun kelompok aktif menggali dan menemukan konsep serta prinsip-prinsip keilmuan secara holistik, bermakna, dan otentik. Pembelajaran tematik berangkat dari pemikiran filosofis tertentu yang menekankan pada pembentukan kreativitas anak didik dengan pemberian aktivitas yang didapat dari pengalaman langsung melalui lingkungannya yang natural.

Peserta didik sebagai subjek dalam kegiatan pembelajaran tematik harus dikondisikan dengan baik. Pertama, peserta didik harus siap mengikuti kegiatan pembelajaran yang dalam pelaksanaannya dimungkinkan untuk bekerja baik secara individual, pasangan, kelompok kecil ataupun klasikal. Kedua, peserta didik harus siap mengikuti kegiatan pembelajaran yang bervariasi secara aktif misalnya melakukan diskusi kelompok, mengadakan penelitian sederhana, dan pemecahan masalah. Permasalahan yang ada di kelas IV UPT.SD Negeri 16 Baringin adalah rendahnya hasil belajar peserta didik pada pembelajaran tematik subtema Keragaman Suku Bangsa dan Agama di Negeriku. Berdasarkan pengamatan peneliti saat proses 
pelaksanaan pembelajaran di kelas, guru masih menggunakan pola pembelajaran konvensional dengan metode ceramah dan penugasan sesuai dengan yang ada di buku peserta didik. Guru sangat dominan dan aktif selama proses pembelajaran berlangsung sehingga antusias peserta didik dalam mengikuti pembelajaran berkurang atau cenderung pasif. Akibatnya berdampak pada kondisi peserta didik yang mudah bosan dan lebih memilih bermain sendiri dari pada memperhatikan guru yang sedang menyampaikan materi

Hasil wawancara dengan guru kelas IV UPT.SD Negeri 16 Baringin, Kondisi peserta didik yang heterogen, dengan kemampuan kognitif yang beragam menjadi kendala tersendiri dalam implementasi pembelajaran tematik. Sebagaimana yang dijelaskan sebelumnya, bahwa implikasi peserta didik dalam pembelajaran tematik harus siap secara pelaksanaan dan variasi kegiatan. Dari data yang diperoleh dalam kegiatan pra siklus diperoleh nilai hasil belajar pada aspek kognitif pembelajaran tematik subtema Keragaman Suku Bangsa dan Agama di Negeriku yang di distribusikan ke dalam 3 mata pelajaran yaitu IPS, PKn, dan Bahasa Indonesia. Pada pembelajaran tematik persentase ketuntasan belajar peserta didik yaitu 54,29\%, dengan nilai rata-rata kelas sebesar 68,29. Hasil belajar peserta didik tersebut secara klasikal termasuk dalam kriteria ketuntasan belajar yang kurang. Maka perlu adanya tindakan perbaikan dalam pembelajaran tematik subtema Keragaman Suku Bangsa dan Agama di Negeriku.

Sebagai pendidik, sebagaimana yang diamanatkan oleh Undang-Undang Sisdiknas nomor 20 tahun 2003 melalui PP nomor 19 tahun 2005, hendaklah mampu menghadirkan proses pembelajaran yang interaktif, inspiratif, menyenangkan, memotivasi, dan menantang. Mengajar adalah upaya membelajarkan subjek didik, bukan mentransfer pengetahuan, dan bukan memintarkan peserta didik. Karenanya, perubahan paradigma pembelajaran yang cenderung menganggap pengetahuan peserta didik kosong, tidak tahu apa-apa, atau seperti kertas putih haruslah segera dirubah total dan bahkan ditinggalkan.

Model pembelajaran adalah suatu perencanaan atau suatu pola yang digunakan sebagai pedoman dalam merencanakan pembelajaran di kelas atau pembelajaran dalam tutorial dan untuk menentukan perangkat-perangkat pembelajaran termasuk di dalamnya, buku-buku, computer, kurikulum dan lain-lain. Soekamto, dkk mengemukakan maksud dari model pembelajaran adalah: "Kerangka konseptual yang melukiskan prosedur yang sistematis dalam mengorganisasikan pengalaman belajar untuk mencapai tujuan tertentu, dan berfungsi sebagai pedoman bagi para perancang pembelajaran dan para pengajar dalam merencanakan aktivitas belajar mengajar".Penggunaan model pembelajaran tertentu memungkinkan guru dapat mencapai tujuan pembelajaran tertentu pula dan bukan tujuan pembelajaran yang lain. Sintaks (pola urutan) dari suatu model pembelajaran menggambarkan keseluruhan urutan alur langkah, menunjukkan dengan jelas kegiatan-kegiatan apa yang perlu dilakukan oleh guru dan peserta didik, urutan kegiatan-kegiatan, dan tugas-tugas khusus yang perlu dilakukan oleh peserta didik. Model pembelajaran mempunyai banyak macam, salah satunya yaitu model pembelajaran Two Stay Two Stray (TSTS).

Model pembelajaran Two Stay Two Stray (TSTS) merupakan bagian dari pembelajaran kooperatif yang memberikan pengalaman kepada peserta didik untuk berbagi pengetahuan baik didalam kelompok maupun dalam kelompok lainnya (Budiyanto, 2016: 151). Model Two Stay Two Stray (Dua Tinggal Dua Tamu), peserta didik dituntut untuk memiliki tanggung jawab dan aktif dalam setiap kegiatan 
pembelajaran. Dalam model pembelajaran ini peserta didik dapat belajar dari teman lainnya dan saling membantu dalam kelompok lainnya, sehingga akan membuat peserta didik aktif dalam pembelajaran. Melalui Model pembelajaran Two Stay Two Stray (TSTS) diharapkan dapat meningkatkan hasil belajar peserta didik pada pembelajaran Tematik Sub Tema Keragaman Suku Bangsa dan Agama di Negeriku. Berdasarkan permasalahan yang tertera di atas, peneliti berkeinginan melakukan penelitian dengan judul: "Peningkatan Hasil Belajar Pembelajaran Tematik Sub Tema Keragaman Suku Bangsa dan Agama di Negeriku Menggunakan Model Two Stay Two Stray (TSTS) Peserta Didik Kelas IV di UPT.SD Negeri 16 Baringin“.

\section{B. Metodologi Penelitian}

Penelitian dalam bahasa Inggris disebut research, "re" artinya kembali, "search" artinya mencari. Jadi research adalah pencarian kembali, yang dicari tentunya jawaban terhadap pertanyaan atau pemecahan terhadap masalah yang dihadapi. Demikian juga pada PTK, membantu guru mengatasi masalah pembelajaran yang dihadapi guru sehari-hari di kelas. Kelas yang dimaksud dalam hal ini bukan berarti kelas fisik atau ruang, tetapi kegiatan pembelajaran dalam suatu mata pelajaran untuk melayani sejumlah peserta didik didalam proses pendidikan dan pengajaran. Tindakan adalah sesuatu yang dilakukan atau perbuatan yang dilaksanakan untuk mengatasi sesuatu (Rosmala Dewi, 2015: 9). Menurut Kemmis, penelitian tindakan adalah suatu bentuk penelitian refleksi diri yang dilakukan oleh para partisipan dalam situasi-situasi sosial (termasuk pendidikan) untuk memperbaiki praktik yang dilakukan sendiri. Subjek dalam penelitian ini adalah siswa kelas IV UPT. SD Negeri 16 Baringin Kecamatan Lima Kaum Kabupaten Tanah Datar yang berjumlah 35 orang yang terdiri dari 19 lakilaki dan 16 perempuan. Tempat pelaksanaan penelitian ini adalah sebagai berikut: Penelitian ini dilaksanakan di UPT. SD Negeri 16 Baringin Kecamatan Lina Kaum Kabupaten Tanah Datar. Adapun pemilihan lokasi ini dikarenakan peneliti sebagai kepala sekolah sehingga dapat memudahkan dan menghemat biaya serta waktu. Ada beberapa ahli yang mengemukakan langkah-langkah penelitian tindakan dengan bagan yang berbeda, namun Arikunto menyatakan bahwa "secara garis besar terdapat empat tahapan yang lazim dilalui, yaitu (1) perencanaan, (2) pelaksanaan, (3) pengamatan, (4) Refleksi”. Dalam mengumpulkan data-data penelitian, teknik yang digunakan peneliti adalah sebagai berikut: 1) Observasi adalah pengamatan dan pencatatan secara sistematik terhadap gejala yang tampak pada objek penelitian. "Observasi merupakan metode pengumpulan data yang menggunakan pengamatan terhadap objek penelitian" (Yatim Rianto,2001: 96). Observasi merupakan pengamatan yang dilakukan oleh guru saat proses pembelajaran berlangsung, saat peserta didik sedang asik berinteraksi membahas pelajaran yang diberikan, atau saat sedang bermain dan lain sebagainya; 2) Wawancara, dalam pelaksanaan penelitian ini wawancara dilakukan dengan guru dan peserta didik kelas IV agar mendapatkan data lebih rinci lagi dari cara sebelumnya sehingga ditemukan permasalahan sebelum penelitian dilakukan; 3) Tes adalah alat atau prosedur yang sistematis dan objektif untuk memperoleh data-data atau keterangan yang diinginkan tentang seseorang, dengan cara yang boleh dikatakan tepat dan cepat. Setiap pertemuan dalam siklus yang dilakukan, siswa akan diberikan tes yang berupa pilihan berganda sebanyak 10 soal. Analisi ini dilakukan untuk mengetahui berhasil atau tidaknya tindakan yang dilakukan dalam penelitian ini. Hal ini dilihat dari persentase tingkat keberhasilan yang dicapai oleh peserta didik kelas UPT. SD Negeri 16 Baringin Kecamatan Lima Kaum Kabupaten Tanah Datar. 


\section{Hasil dan Pembahasan Deskripsi Paparan Siklus}

Penelitian ini dilakukan di UPT. SD Negeri 16 Baringin. Penelitian ini menggunakan medel Two Stay Two Stray ( TSTS ) sebagai suatu upaya dalam meningkatkan hasil belajar pembelajaran Tematik Sub Tema Keragaman Suku Bangsa dan Agama di Negeriku siswa kelas IV.Tahapan pertama yang dilakukan oleh peneliti sebelum dilakukannya perencanaan dan tindakan adalah pemberian tes awal kepada peserta didik. Tujuan pemberian tes awal sebelum melakukan perencanaan adalah untuk mengetahui sejauh mana kemampuan awal peserta didik dalam memperoleh hasil belajar pembelajaran Tematik Sub Tema Keragaman Suku Bangsa dan Agama di Negeriku. Dari 35 siswa di kelas IV, dapat diketahui bahwa hasil belajar peserta didik pada tes awal sebagai berikut :

\section{Tabel Hasil Perolehan Belajar Peserta Didik pada Tes Awal}

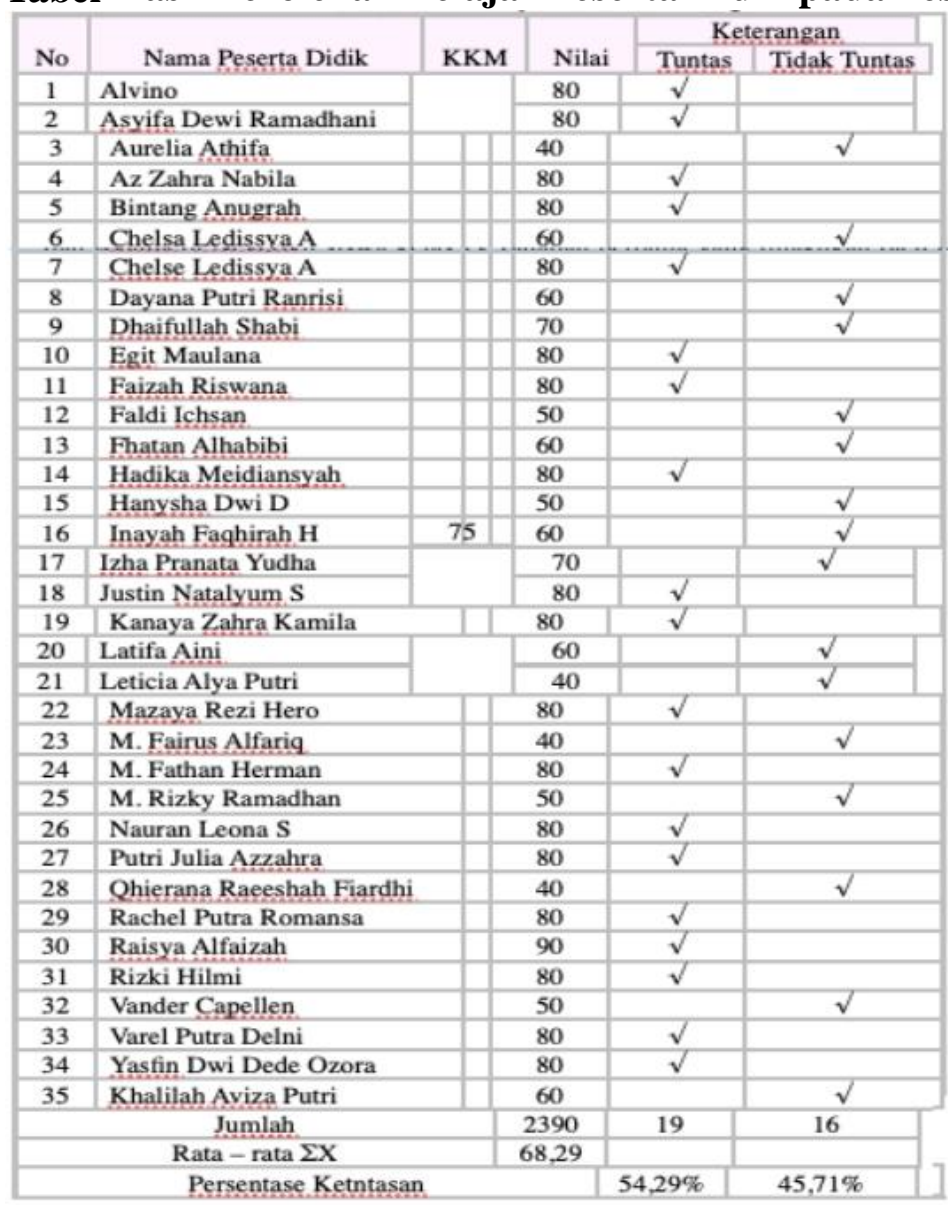

Berdasarkan tabel di atas, rata-rata kelas yang diperoleh adalah 68,29 peserta didik yang mencapai KKM (75) sejumlah 19 orang atau sebesar 54,29\% sedangkan peserta didik yang nilainya belum mencapai KKM sejumlah 16 orang atau sebesar 45,71\% dan nilai rata-rata sebesar 68,29. Apabila pencapaian hasil belajar peserta didik pada kondisi awal disajikan dalam bentuk diagram sebagai berikut: Diagram Hasil Perolehan peserta didik pada Pra Siklus.

\section{Deskripsi Penelitian Siklus I}

Tahap ini dilakukan setelah mengetahui permasalahan yang terdapat pada peserta didik berdasarkan hasil wawancara terhadap wali kelas selaku guru pembelajaran 
Tematik Sub Tema Keragaman Suku Bangsa dan Agama di Negeriku. Maka dilakukan tes awal yang bertujuan untuk melihat sejauh mana pemahaman peserta didik terhadap materi tersebut. Permasalahan yang kerab terjadi pada peserta didik: a) Peserta didik mengalami kesulitan dalam memahami materi sehingga menimbulkan rasa tidak peduli terhadap pembelajaran; b) Peserta didik belum terbiasa untuk mengajukan pertanyaan; c) Peserta didik belum terbiasa maju kedepan kelas untuk mempersentasikan hasil diskusi kelompok. Diakhir pelaksanaan siklus I, siswa diberikan tes hasil belajar yang bertujuan untuk melihat keberhasilan tindakan yang diberikan setelah menggunakan model Two Stay Two Stray ( TSTS ).

Adapun data hasil belajar peserta didik pada siklus I dapat dilihat pada tabel di bawah ini

\section{Tabel Hasil Nilai Evaluasi Peserta Didik Siklus I}

\begin{tabular}{|c|c|c|c|c|c|}
\hline \multirow[b]{2}{*}{ No } & \multirow[b]{2}{*}{ Nama Peserta Didik } & \multirow[b]{2}{*}{$\mathrm{KKM}$} & \multirow[b]{2}{*}{ Nilai } & \multicolumn{2}{|c|}{ Keterangan. } \\
\hline & & & & Tuntas & Tidak \\
\hline 1 & Alvino & & 80 & $\sqrt{ }$ & \\
\hline 2 & Asyifa Dewi Ramadhani & & 80 & $\sqrt{ }$ & \\
\hline 3 & Aurelia Athifa & & 50 & & $\sqrt{ }$ \\
\hline 4 & Az. Zahra Nabila & 75 & 90 & $\sqrt{ }$ & \\
\hline 5 & Bintang Anugrah & & 80 & $\sqrt{ }$ & \\
\hline 6 & Chelsa Ledissya A & & 80 & $\sqrt{ }$ & \\
\hline 7 & Chelse Ledissya A & & 80 & $\sqrt{ }$ & \\
\hline 8 & Dayana Putri Ranrisi & & 70 & & $\sqrt{ }$ \\
\hline 9 & Dhaifullab Shabi & & 80 & $\sqrt{ }$ & \\
\hline 10 & Egit Maulana & & 90 & $\sqrt{ }$ & \\
\hline 11 & Faizah Riswana. & & 80 & $\sqrt{ }$ & \\
\hline 12 & Faldi Ichsan & & 60 & & $\sqrt{ }$ \\
\hline 13 & Fhatan Alhabibi & & 80 & $\sqrt{ }$ & \\
\hline 14 & Hadika Meidiansyab. & & 80 & $\sqrt{ }$ & \\
\hline 15 & Hanysha Dwi D & & 60 & & $\sqrt{ }$ \\
\hline 16 & Inayah Faghirah $\mathbf{H}$ & & 80 & $\sqrt{ }$ & \\
\hline 17 & Izha Pranata Yudha & & 80 & $\sqrt{ }$ & \\
\hline 18 & Justin Naraivum S & & 80 & $\sqrt{ }$ & \\
\hline 19 & Kanaya Zahra Kamila & & 90 & $\sqrt{ }$ & \\
\hline 20 & Latifa Aini & \multirow{2}{*}{75} & 80 & $\sqrt{ }$ & \\
\hline 21 & Leticia Alya Putri & & 40 & & $\sqrt{ }$ \\
\hline 22 & \multicolumn{2}{|l|}{ Mazaya Rezi Hero } & 80 & $\sqrt{ }$ & \\
\hline 23 & \multicolumn{2}{|l|}{ M. Fairus Alfariq. } & 50 & & $\sqrt{ }$ \\
\hline 24 & \multicolumn{2}{|l|}{ M. Fathan Herman } & 80 & $\sqrt{ }$ & \\
\hline 25 & \multicolumn{2}{|l|}{ M. Rizky Ramadhan } & 60 & & $\sqrt{ }$ \\
\hline 26 & \multicolumn{2}{|l|}{ Nauran Leona S } & 80 & $\sqrt{ }$ & \\
\hline 27 & \multicolumn{2}{|l|}{ Putri Julia Azrahra } & 80 & $\sqrt{ }$ & \\
\hline 28 & \multicolumn{2}{|l|}{ Qhierana Raeeshah Fiardhi. } & 40 & & $\sqrt{ }$ \\
\hline 29 & \multicolumn{2}{|l|}{ Rachel Putra Romansa } & 80 & $\sqrt{ }$ & \\
\hline 30 & \multicolumn{2}{|l|}{ Raisya Alfaizah } & 90 & $\sqrt{ }$ & \\
\hline 31 & \multicolumn{2}{|l|}{ Rizki Hilmi } & 80 & $\sqrt{ }$ & \\
\hline 32 & \multicolumn{2}{|l|}{ Vander Capellen. } & 60 & & $\sqrt{ }$ \\
\hline 33 & \multicolumn{2}{|l|}{ Varel Putra Delni } & 80 & $\sqrt{ }$ & \\
\hline 34 & \multicolumn{2}{|l|}{ Yasfin Dwi Dede Ozora } & 90 & $\sqrt{ }$ & \\
\hline 35 & \multicolumn{2}{|l|}{ Khalilah Aviza Putri } & 80 & $\sqrt{ }$ & \\
\hline \multicolumn{3}{|c|}{ Jumlah. } & 2620 & 26 & 9 \\
\hline \multicolumn{3}{|c|}{ Rata - rata $\mathbf{\Sigma X}$} & 74.86 & & \\
\hline \multicolumn{4}{|c|}{ Persentase Ketntasan } & $74.29 \%$ & $25,71 \%$ \\
\hline
\end{tabular}

Dari data diatas perolehan nilai tes hasil belajar siklus II siswa kelas IV UPT. SD Negeri 16 Baringin menunjukkan bahwa dari 35 orang terdapat 26 orang $(74,29 \%)$ dengan nilai $\geq 75$ yang dikatakan tuntas belajar. Hal tersebut dikarenakan peserta didik sudah mulai aktif dalam pembelajaran sehingga mudah untuk menjawab soal latihan yang diberikan, serta peserta didik sudah mulai menunjukkan keberanian untuk berbicara didepan kelas dan bertanya tentang apa yang kurang dipahami. Sedangkan 9 
orang $(25,71 \%)$ lainnya belum mencapai nilai $\geq 75$ dinyatakan tidak tuntas. Hal ini dikarenakan masih ada peserta didik yang kurang berpartisipasi serta masih rendahnya pengetahuan peserta didik mengenai materi pembelajaran Tematik Sub Tema Keragaman Suku Bangsa dan Agama di Negeriku. Berdasarkan hasil perhitungan persentase ketuntasan klasikal sebelumnya $(54,29 \%)$ dan pada siklus I $(74,29 \%)$, maka dapat diketahui bahwa terjadi peningkatan sebesar 20\%. Hal tersebut dikarenakan proses belajar mengajar dilakukan dengan menggunakan model Two Stray Two Stay ( TSTS ). Meski demikian, keberhasilan proses belajar mengajar pada siklus I masih belum tercapai karena belum sesuai dengan persentase ketuntasan secara klasikal yaitu $\geq 85 \%$.

Data dari tabel di atas mengenai hasil belajar pembelajaran Tematik Sub Tema Keragaman Suku Bangsa dan Agama di Negeriku pada pembelajaran 3 peserta didik pada siklus I dapat diperjelas melalui diagram di bawah ini.

Gambar Hasil Perolehan Belajar peserta didik pada Siklus I. Keberhasilan dan kegagalan yang terjadi dalam pelaksanaan siklus I dapat diuraikan sebagai berikut :

1. Berdasarkan hasil observasi pembelajaran semua aspek dalam pembelajaran model Two Stay Two Stray (TSTS) berjalan dengan baik.

2. Berdasarkan hasil wawancara dengan peserta didik yang mengalami kesulitan belajar, peserta didik kurang memahami pertanyaan yang tertera di dalam lembar kerja

3. Beberapa peserta didik kurang teliti dalam menjawab beberapa pertanyaan yang ada di lembar kerja

4. Terdapat peserta didik yang pasif dan tidak berpartisipasi di dalam kelompoknya

5. Kurangnya kepercayaan diri peserta didik saat menyampaikan hasil diskusi dan mengemukakan pendapat

6. Ada beberapa peserta didik yang belum mampu menerapkan model Two Stay Two Stray (TSTS) dalam materi pembelajaran Tematik Sub Tema Keragaman Suku Bangsa dan Agama di Negeriku pada pembelajaran 3.

Dilihat dari hasil yang diperoleh pada siklus I masih belum sesuai dengan yang diharapkan, maka peneliti memutuskan untuk melanjutkan penelitian ke siklus berikutnya untuk memperbaiki permasalahan-permasalahan yang terjadi di siklus I.

\section{Deskripsi Penelitian Siklus II}

Berdasarkan hasil yang diperoleh dari siklus I, masih belum sesuai dengan hasil yang diharapkan. Data di atas menunjukkan bahwa peserta didik mengalami kesulitan dalam menyelesaikan soal-soal yang diberikan. Untuk memperbaiki dan mengatasi kelemahan dan kesulitan pada siklus I, maka pada siklus II. Diakhir pelaksanaan siklus II, peserta didik diberikan tes hasil belajar yang bertujuan untuk melihat keberhasilan tindakan yang diberikan setelah menggunakan model Two Stay Two Stray ( TSTS ).

Adapun data hasil belajar siswa pada siklus II dapat dilihat pada tabel di bawah ini 
Tabel Hasil Nilai Evaluasi Peserta didik Siklus II

\begin{tabular}{|c|c|c|c|c|c|}
\hline \multirow[b]{2}{*}{ No } & \multirow[b]{2}{*}{ Nama Peserta Didik } & \multirow[b]{2}{*}{ KKM } & \multirow[b]{2}{*}{ Nilai } & \multicolumn{2}{|c|}{ Keterangan } \\
\hline & & & & Tuntas & Tidak \\
\hline 1 & Alvino & & 80 & $\sqrt{ }$ & \\
\hline 2 & Asyifa Dewi Ramadhani & & 80 & $\sqrt{ }$ & \\
\hline 3 & Aurelia Athifa & 75 & 70 & & $\sqrt{ }$ \\
\hline 4 & Az Zahra Nabila & & 100 & $\sqrt{ }$ & \\
\hline 5 & Bintang Anugrah & & 80 & $\sqrt{ }$ & \\
\hline 6 & Chelsa Ledissya A & & 90 & $\sqrt{ }$ & \\
\hline 7 & Chelse Ledissya. A & & 100 & $\sqrt{ }$ & \\
\hline 8 & Dayana Putri Ranrisi & & 80 & $\sqrt{ }$ & \\
\hline 9 & Dhaifullah Shabi & & 80 & $\sqrt{ }$ & \\
\hline 10 & Egit Maulana & & 100 & $\sqrt{ }$ & \\
\hline 11 & Faizah Riswana. & & 100 & $\sqrt{ }$ & \\
\hline 12 & Faldi Ichsan & & 80 & $\sqrt{ }$ & \\
\hline 13 & Fhatan Alhabibi & & 80 & $\sqrt{ }$ & \\
\hline 14 & Hadika Meidiansyah & & 80 & $\sqrt{ }$ & \\
\hline 15 & Hanysha Dwi D & & 80 & $\sqrt{ }$ & \\
\hline 16 & Inayah Faghirah $\mathrm{H}$ & & 80 & $\sqrt{ }$ & \\
\hline 17 & Izha Pranata Yudha & & 80 & $\sqrt{ }$ & \\
\hline 18 & Justin Natalyum S & & 80 & $\sqrt{ }$ & \\
\hline 19 & Kanaya Zahra Kamila & 75 & 100 & $\sqrt{ }$ & \\
\hline 20 & Latifa Aini & & 80 & $\sqrt{ }$ & \\
\hline 21 & \begin{tabular}{|l} 
Leticia Alya Putri \\
\end{tabular} & & 70 & $\sqrt{ }$ & \\
\hline 22 & Mazaya Rezi Hero & & 100 & & $\sqrt{ }$ \\
\hline 23 & M. Fairus Alfarig & & 50 & & $\sqrt{ }$ \\
\hline 24 & M. Fathan Herman & & 100 & $\sqrt{ }$ & \\
\hline 25 & M. Rizky Ramadhan & & 80 & $\sqrt{ }$ & \\
\hline 26 & Nauran Leona $\mathrm{S}$ & & 80 & $\sqrt{ }$ & \\
\hline 27 & Putri Julia Azzahra & & 80 & $\sqrt{ }$ & \\
\hline 28 & Qhierana Raeeshab Fiardbi & & 60 & & $\sqrt{ }$ \\
\hline 29 & Rachel Putra Romansa & & 80 & $\sqrt{ }$ & \\
\hline 30 & Raisya Alfaizah & & 100 & $\sqrt{ }$ & \\
\hline 31 & Rizki Hilmi & & 90 & $\sqrt{ }$ & \\
\hline 32 & Vander Capellen & & 80 & $\sqrt{ }$ & \\
\hline 33 & \begin{tabular}{|l} 
Varel Putra Delni \\
\end{tabular} & & 90 & $\sqrt{ }$ & \\
\hline 34 & Yasfin Dwi Dede Ozora & & 100 & $\sqrt{ }$ & \\
\hline 35 & Khalilah Aviza Putri & & 100 & $\sqrt{ }$ & \\
\hline \multicolumn{3}{|c|}{ Jumlah } & 2960 & 31 & 4 \\
\hline \multirow{2}{*}{\multicolumn{3}{|c|}{$\frac{\text { Rata - rata } \Sigma \mathrm{X}}{\text { Rersentase. Ketntas }}$}} & 84,57 & & \\
\hline & & & & $8.57 \%$ & $11,43 \%$ \\
\hline
\end{tabular}

Dari data diatas perolehan nilai tes hasil belajar siklus II dapat dinyatakan tuntas dalam pencapaian pembelajaran yang diberikan secara maksimal kepada peserta didik kelas IV UPT. SD Negeri 16 Baringin. Data tersebut menunjukkan bahwa dari 35 peserta didik yang mengikuti tes hasil belajar pada siklus II terdapat 31 orang $(88,57 \%)$ pembelajaran Tematik Sub Tema Keragaman Suku Bangsa dan Agama di Negeriku pada pembelajan 4 dan keaktifan peserta didik di dalam kelas saat proses kegiatan di dalam kelas, baik bertanya maupun menananggapi pertanyaan. Namun masih di sayangkan masih terdapat 4 orang $(11,43 \%)$ yang memperoleh nilai $<75$ hal ini disebabkan kemauan belajar peserta didik yang rendah sehingga dinyatakan tidak tuntas dalam pembelajaran Tematik Sub Tema Keragaman Suku Bangsa dan Agama di Negeriku pada pembelajan 4. Sehingga dapat dikatan bahwa hasil belajar peserta didik pada materi pembelajaran Tematik Sub Tema Keragaman Suku Bangsa dan Agama di Negeriku pada pembelajan 4 mulai dari awal pembelajaran hingga akhir pertemuan dinyatakan maksimal dengan ketuntasan klasikal melebihi 85\% dan rata-rata 84,57. Peningkatan tersebut dikarenakan meningkatnya aktivitas peserta didik saat proses 
kegiatan belajar pembelajaran Tematik Sub Tema Keragaman Suku Bangsa dan Agama di Negeriku pada pembelajan 4 didalam kelas, peserta didik mampu menyelesaikan masalah-masalah yang diberikan oleh guru,dan peserta didik juga aktif dalam kegiatan kelompok.

Data dari tabel di atas mengenai hasil belajar pembelajaran Tematik Sub Tema Keragaman Suku Bangsa dan Agama di Negeriku pada pembelajan 4 peserta didik pada siklus II dapat diperjelas melalui diagram di bawah ini. Diagram Hasil Perolehan Belajar Peserta Didik pada Siklus II. Berdaasarkan hasil observasi dan tes dapat dikatakan bahwa peneliti telah mampu mempertahankan dan meningkatkan pelaksanaan kegiatan pembelajaran dengan menggunakan model Two Stay Two Str ( TSTS) Hal ini didasarkan pada hasil observasi yang menunjukkan peningkatan kegiatan pembelajaran yang semakin membaik berdasarkan pengamatan observer. Begitu juga dengan tes hasil belajar yang mengalami peningkatan. Persentase yang ditunjukkan pada siklus II sudah melebihi dari $85 \%$, ini berarti ketuntasan belajar klasikal sudah tercapai, sehingga penelitian tidak dilanjutkan pada siklus berikutnya.

\section{Pembahasan Hasil Penelitian}

Penelitian ini dilaksanakan untuk mengetahui apakah model pembelajaran Two Stay Two Stray ( TSTS ) dapat meningkatkan hasil belajar pembelajaran Tematik Sub Tema Keragaman Suku Bangsa dan Agama di Negeriku kelas IV, UPT. SD Negeri 16 Baringin Kecamatan Lima Kaum Kabupaten Tanah Datar. Jenis penelitian ini adalah penelitian tindakan kelas, maka peneliti mencoba menjabarkan pembahasan penelitian ini berdasarkan siklus yang sudah dilakukan yaitu siklus I dan siklus II. Sebelum melaksanakan tindakan siklus I dan II peneliti lebih dulu memberikan tes awal (pra siklus) yang bertujuan untuk mengetahui sejauh mana anak memahami materi pembelajaran Tematik Sub Tema Keragaman Suku Bangsa dan Agama di Negeriku dan apa saja yang menjadi persoalan bagi anak saat membahas materi tersebut. Pada tes inilah dimulainya perencanaan tindakan yang akan dilakukan oleh peneliti di siklus I dan siklus berikutnya. Berdasarkan dari hasil tes awal di kelas IV persentasi ketuntasan klasikal diperoleh 54,29\% (19 orang), dikarenakan peserta didik belum sepenuhnya memahami materi tentang pembelajaran Tematik Sub Tema Keragaman Suku Bangsa dan Agama di Negeriku yang telah diajarkan sebelumnya oleh wali kelas IV. Sedangkan persentase yang tidak tuntas 45,71\% (16 orang), dikarenakan kurangnya pengetahuan peserta didik tentang materi pembelajaran Tematik Sub Tema Keragaman Suku Bangsa dan Agama di Negeriku yang sebelumnya telah diajarkan oleh wali kelas IV. Maka peneliti melakukan rencana dan tindak lanjut untuk memperbaiki hasil belajar pembelajaran Tematik Sub Tema Keragaman Suku Bangsa dan Agama di Negeriku pada pembelajan peserta didik.

Proses pembelajaran pada siklus I. Waktu yang digunakan adalah satu kali pertemuan atau 1 hari ( 8 x 35 menit). Pada pertemuan di siklus I sebelum proses pembelajaran dimulai lebih dulu peneliti menjelaskan tujuan pembelajaran yang akan dicapai dan memotivasi peserta didik, serta menjelaskan tentang model pembelajaran apa yang akan digunakan dalam proses pembelajaran yang akan dilaksanakan. Kemudian peneliti menjelaskan materi sekaligus menampilkan media pembelajaran dan membagi peserta didik menjadi beberapa kelompok belajar. Pada pertemuan siklus I masih terdapat banyak kekurangan selama proses pembelajaran, antara lain : peneliti masih sulit untuk mengkondusifkan kelas pada saat membagi peserta didik ke dalam beberapa kelompok belajar. Selain itu, interaksi antar peserta didik dalam 
kelompoknya belum maksimal sehingga peserta didik mengerjakan permasalahan yang diberikan secara individual.

Proses pembelajaran pada siklus II. waktu yang digunakan adalah 1 kali pertemuan atau 1 hari ( 8 x 35 menit). Pada siklus II ini proses pembelajaran sudah lebih baik dari pada siklus sebelumnya. hal ini terlihat dari semakin aktif dan membaiknya interaksi antar teman kelompok belajarnya, baik saat bertanya, menjawab dan menjelaskan hasil permasalahan yang dimiliki kelompoknya maupun kelompok belajar lainnya.

Ketuntasan Hasil Belajar. Nilai KKM (kriteria ketuntasan minimal) yang telah ditetapkan di kelas IV UPT. SD Negeri 16 Baringin Kecamatan Lima Kaum Kabupaten Tanah Datar pada pembelajaran Tematik Sub Tema Keragaman Suku Bangsa dan Agama di Negeriku adalah 75 sedangkan ketuntasan klasikal 85\% sebagaimana yang telah ditetapkan di sekolah tersebut. Untuk mengetahui pengetahuan peserta didik telah mencapai ketuntasan hasil belajar maka dilakukanlah tes. Setiap peserta didik dikatakan tuntas belajarnya (ketuntasan individu) jika hasil belajar peserta didik mencapai 75 atau melebihi KKM (kriteria ketuntasan minimal) yang telah ditentukan di sekolah tersebut. Dari tes hasil belajar pada siklus I hanya terdapat 26 orang $(74,29 \%)$ peserta didik yang mencapai ketuntasan secara individu. Jika dilihat secara klasikal ini juga belum mencapai tuntas karena terdapat 9 siswa $(25,71 \%)$ peserta didik yang belum mencapai ketuntasan.

Ketuntasan hasil belajar pada siklus II mengalami peningkatan, dari hasil persentase nilai yang diperoleh yaitu 31 orang $(88,57 \%)$ peserta didik yang mencapai ketuntasan sedangkan $4(11,43 \%)$ peserta didik yang tidak tuntas, hal ini disebabkan pada siklus II peserta didik sudah mulai serius dan dapat memahami materi pembelajaran Tematik Sub Tema Keragaman Suku Bangsa dan Agama di Negeriku, dengan demikian adanya perbedaan hasil belajar yang terdapat di siklus I dan hasil belajar di siklus II. Jadi dapat disimpulkan bahwa model pembelajaran Two Stay Two Stray (TSTS) dan dibantu oleh media pembelajaran yang disajikan oleh peneliti dapat meningkatkan hasil belajar peserta didik dalam pembelajaran Tematik Sub Tema Keragaman Suku Bangsa dan Agama di Negeriku. berikut :

Ketuntasan belajar klasikal pada siklus I dan siklus II diperoleh data sebagai

Tabel Hasil Tes Belajar Siswa pada Siklus I dan II

\begin{tabular}{|l|c|c|c|c|}
\hline \multirow{2}{*}{ Kategori } & Nilai Tes Belajar Siklus I & $\begin{array}{c}\text { Nilai Tes Belajar Siklus } \\
\text { II }\end{array}$ & & \\
\cline { 2 - 5 } & Angka & Persen & Angka & Persen \\
\hline Nilail $\geq 75$ & 26 Siswa & $74,29 \%$ & $\begin{array}{c}31 \\
\text { Siswa }\end{array}$ & $88,57 \%$ \\
\hline Nilai $<75$ & 9 Siswa & $74,29 \%$ & 4 Siswa & $11,43 \%$ \\
\hline Nilai rata-rata & 74,89 & 84,57 & & \\
\hline $\begin{array}{l}\text { Ketuntasan } \\
\text { klasikal }\end{array}$ & $74,29 \%$ & $88,57 \%$ & & \\
\hline
\end{tabular}

Dari tabel diatas dapat dilihat bahwa ada peningkatan hasil belajar peserta didik antara siklus I dan siklus II. Hal ini dapat dilihat dari: 1) Pertambahan nilai rata-rata kelas. Nilai rata-rata pada tes hasil belajar siklus I adalah 74,89 dan pada tes hasil belajar siklus II adalah 84,57. Dengan demikian terjadi peningkatan nilai rata-rata 
sebesar 9,68. Hal ini karena meningkatnya kemauan peserta didik dalam belajar dan menyelesaikan permasalahan yang diberikan pada materi pembelajaran Tematik Sub Tema Keragaman Suku Bangsa dan Agama di Negeriku dengan menggunakan model Two Stay Two Stray (TSTS); 2) Pertambahan jumlah siswa yang memperoleh nilai $\geq$ 75. Pada tes hasil belajar siklus I jumlah siswa yang memperolen nilai $\geq 75$ sebanyak 26 orang, sedangkan pada tes hasil belajar siklus II sebanyak 31 orang; dan 3) Peningkatan persentase ketuntasan klasikal. Pada siklus I persentase ketuntasan klasikal sebesar 74,29\% dan pada siklus II persentase ketuntasan klasikal sebesar $88,57 \%$. Dengan demikian mengalami peningkatan sebesar $14,28 \%$. Pada siklus ini telah dilakukan proses kegiatan belajar dengan baik serta memperbaiki kesalahankesalahan yang terjadi sebelumnya.

\section{Penutup}

Berdasarkan hasil penelitian dengan metode pembelajaran Two Stay Two Stray (TSTS) pada pembelajaran Tematik Sub Tema Keragaman Suku Bangsa dan Agama di Negeriku.di kelas IV UPT. SD Negeri 16 Baringin Kecamatan Lima Kaum kabupaten Tanah Datar, maka dapat dikemukakan kesimpulan dan saran-saran sebagai berikut: Berdasarkan hasil penelitian dan hasil analisis data, penulis dapat menyimpulkan bahwa, berdasarkan tes awal (Pre-Test) yang diberikan sebelum menggunakan pembelajaran model Two Stay Two Stray (TSTS) diperoleh 19 orang $(54,29 \%)$ yang mencapai ketuntasan belajar dan 16 orang $(45,71 \%)$ yang belum mencapai ketuntasan belajar pembelajaran Tematik Sub Tema Keragaman Suku Bangsa dan Agama di Negeriku, nilai rata-rata kelas yang di dapat pada kelas IV ini sebesar 68,29. Pembelajaran menggunakan model Two Stay Two Stray (TSTS) dalam pembelajaran Tematik Sub Tema Keragaman Suku Bangsa dan Agama di Negeriku dapat menarik perhatian peserta didik, hal ini dapat dilihat dari keaktifan peserta didik saat kegiatan pembelajaran berlangsung baik di dalam kelompok belajar maupun individu saat menjelaskan hasil diskusinya. Peningkatan hasil belajar setelah menggunakan model Two Stay Two Stray (TSTS) pada pembelajaran Tematik Sub Tema Keragaman Suku Bangsa dan Agama di Negeriku terhadap peserta didik dikatakan berhasil. Hal ini dapat dilihat dari tes yang diberikan kepada peserta didik, tes hasil belajar pada siklus I nilai rata-rata kelas yang di dapat siswa sebesar 74,89 jumlah peserta didik yang telah mencapai ketuntasan belajar sebanyak 26 orang $(74,29 \%)$ dan jumlah peserta didik yang belum mencapai ketuntasan belajar sebanyak 9 siswa $(25,71 \%)$. Sedangkan tes hasil belajar siklus II nilai rata-rata kelas yang didapat peserta didik sebesar 84,57, jumlah peserta didik yang mencapai ketuntasan belajar sebanyak 31 orang $(88,57 \%)$ dan jumlah peserta didik yang tidak tuntas belajar sebanyak 4 orang $(11,43 \%)$. Dapat disimpulkan bahwa nilai rata-rata kelas yang di dapat peserta didik mengalami peningkatan sebesar 8,93\% dan ketuntasan belajar peserta didik secara klasikal meningkat sebesar $28,57 \%$. Hasil observasi guru pada siklus I diperoleh nilai rata-rata sebesar 3,33 dan hasil observasi guru siklus II adalah sebesar 3,80 dengan kategori sangat baik. Dengan demikian dapat disimpulkan bahwa observasi guru mengalami peningkatan sebesar 0,47 .

\section{Daftar Pustaka}

Budiyanto, Krisno Agus Moch. 2016. Sintaks 45 Metode Pembelajaran Dalam Student Centered Learning (SCL). Malang: Universitas Muhammadiyah Malang.

Dewi, Rosmala. 2015. Penelitian Tindakan Kelas. Medan: Unimed Pers 
Fathurrohman, M. 2017. Belajar dan Pembelajaran Modern. Yogyakarta: Garudhawaca.

Istarani. 2011. Model Pembelajaran Inovatif. Medan: Media Persada.

Kadir,Abd dan Hanum Asrohah, 2014. Pembelajaran Tematik (Jakarta: Raja Grafindo Persada.

Majid, Abdul.2014. Pembelajaran Tematik Terpadu.Bandung: Remaja Rosda Karya.

Mardianto. 2013. Teknik Pengelompokkan Siswa. Medan: IAIN Press.

Masitoh, dkk. 2009. Strategi Pembelajaran. Jakarta: Depag RI.

Muhlisrarini dan Ali Hamzah. 2014. Perencanaan dan Strategi Pembelajaran Matematika. Jakarta: PT RajaGrafindo Persada.

Riyanto, Yatim. 2001., Metodologi Penelitian suatu Tindakan Dasar, Surabaya: Sie Surabaya,

Rofiq, Nafiur M. 2010. Pembelajaran Kooperatif (Cooperative Learning) dalam Pengajaran Pendidikan Agama Islam. Jurnal Falasifa: No. 1. Vol. 1.

Slameto. 2010. Belajar dan Factor-faktor yang Mempengaruhi. Jakarta: Rineka Cipta.

Sukmadinanto, Syaodih Nana. 2005. Landasan Psikologi Proses Pendidikan. Bandung: PT. Remaja Rosdakarya. 